\author{
DR. A. Gergely ANDrás PhD
}

andrasgergelya@gmail.com

oktató (ELTE, SZTE)

\title{
Éltünk, s ebbe más is belenyekkent már...
}

Ha van még integráció, s van még felépítmény

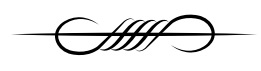

DOI 10.14232/belv.2020.2.9

https://doi.org/10.14232/belv.2020.2.9

Cikkre való hivatkozás / How to cite this article:

A. Gergely András: (2020): Éltünk, s ebbe más is belenyekkent már... Belvedere Meridionale 32. évf. 2. sz. 175-185. pp

ISSN 1419-0222 (print) ISSN 2064-5929 (online, pdf)

(Creative Commons) Nevezd meg! - Így add tovább! 4.0 (CC BY-SA 4.0)

(Creative Commons) Attribution-ShareAlike 4.0 International (CC BY-SA 4.0)

www.belvedere-meridionale.hu

KovÁcH ImRE (szerk.) (2017): Társadalmi integráció - Az egyenlőtlenségek, az együttmüködés, az újraelosztás és a hatalom szerkezete a magyar társadalomba. Szeged, MTA Társadalomtudományi Kutatóközpont Szociológiai Intézet - Belvedere Meridionale. 378 oldal

A kortárs társadalmak müködésmódjának leírásához a hatvanas évek második fele, hetvenesek eleje óta kínálkozik olyan tudományos eszköztár, melynek eredeti kimunkálása részint a német, ,értékmentes” társadalomfelfogási-kutatási alapokon (Weber, Offe, Habermas), részint az amerikai társadalomszerkezet-modelleken épült fel (Parsons, Lippmann, Bachrach, Baratz, Lipset, Easton). Ezek kutatási irányzatai már a hetvenes évek közepétől két főirányt formáltak: a teoretikus magaslatok szintjét, meg az adatbázisra, „empirikus kutatásra” fölmagasuló rendszerfogalmak kezdeményeit. A magyar társadalomkutatás a mikro-szintű (szociografikus, publicisztikai) valóságismeret felől indult a makro-szintü feltárás, az „egyrétegü” társadalom-modell képzetétől a többes rétegződést lehetővé tevő makro-modellezés felé (Andorka, Kolosi, 
Hankiss, Angelusz, Tardos). Mindkettő hagyománya megmaradt, és más-más szinteken, néha eltérő tudomány- vagy tudásterületeken jelentkezik ma is. Közben valamely helyzetcsere is kialakulni látszott: a nagy empirikus bázisokat kis közvetlen ismeretanyaggal pontosították, a kicsiny közösségek tapasztalatát meg az univerzálisra emlékeztető elöképek, párhuzamok mentén színezték „általánosabb” tapasztalati tónusúvá. A rendszerfogalmak és az „életvilágok” fogalma között keletkezés- és ismerettörténeti nézőpontok is megjelentek (Papp Zsolt, Pokol Béla, Sik Endre), és a társas lét struktúrái is fel-feltünedeztek a pszichológiai mélységü megközelítések keretezéseként (Losonczi Ágnes, Ferge Zsuzsa, Utasi Ágnes). Amikor ezeket a rétegződés- és struktúra-modelleket alkalmazni biztosak idővel az „ontológiai” mélységü belátások irányába fordulnak, rendre megjelennek köztes fogalmak is, melyek azután (vagy olykor-olykor, de kitartó módon) sokszor évtizedekre is kihatnak, valamint gondolkodás- és megközelítésmódokat alapoznak meg, bővítenek ki vagy serkentenek. Ez utóbbiak tünete olykor, hogy a fogalmi készlet, az egyének társadalmi helye és helyzete szempontjából minőségi másságokat is magába foglaló kiegészülések cizellálják az ismereteket: a cselekvések és müködési rendszerek egymásközti viszonyában ezért néha nem a váz, az építmény milyensége, kiterjedése, magassága, szintjeinek távolsága, hanem az átjárások, a le- vagy felfelé mozgás, a mobilitás, a térbeli helycserék pontosítják a társadalmi rendszer egészének müködésmódját. Ennek elvi, „univerzális” szintje szokott lenni a társadalmi nagycsoportok egymásközti viszonyrendszere, divatosabb fogalommal az integráció mikéntje, a társas univerzum. Ez már magába foglalhat rétegjellemzőket és mozgásokat, kiterjedés-változásokat és függésrendeket, hosszú távú átalakulásokat, sokmenetes történéseket, hanyatlásokat és kimagaslásokat, cikk-cakkokat és hullámzásokat, alakváltozást vagy visszakanyarodást is akár. S majd csak erre jön a további finomítás kérdése: miképpen alakul a rétegek sora, ezeken belül a rendszer egyéb komponenseinek kölcsönhatása, a hatalom intézménye és beágyazottsága, a korcsoportok-korosztályok témakörei, a partnerségek, együttmüködések rendszere, a kitettségek és áttételes hatások váratlanságai, a strukturális változásban a funkcionális működésmódok számos változata, stb. Mármost a társadalmak ezt a berendezkedéssel, uralmi formával, a munka és piac és gazdaság alrendszereivel, a képzettséggel, a korosztályok kapcsolatrendjével (stb., stb.) összefüggő nagy-nagy instrumentális konstrukciót egészítik ki a mindennapi létezés ésszerüségeivel, a racionalitások vagy rendszertelen kölcsönhatások sokrétegü és sokkörös mechanizmusaival, vagyis a kommunikatív, kölcsönhatásokra is épülő racionalitások elméleti (és eszmetörténetileg is régtől továbbvezethető) sajátosságaival. ${ }^{1}$

Jószerével ez lehet sokféle társadalomismeret alapja, politikai rend működésformája, önkép és szereptudat bázisa - sosem árthat tehát tudnunk arról, mi és hogyan, mikortól és mi módon áll úgy, ahogy haladni vagy megtorpanni látszik. Ezt a fajta „hibrid” ismeretanyagot tekintheti társadalomleíró modellnek az, aki e rétegződési kérdések megértése irányában nyitott, s ezt kínálja az a kötet is, melyet a szegedi Balvedere Meridionale kiadó 2017-ben megjelentetett Társadalmi integráció - Az egyenlötlenségek, az együttmüködés, az újraelosztás és a hatalom szerkezete a magyar társadalomban címen. ${ }^{2}$ A társadalomkutatók színterén egyfelöl vannak többen is, akik szentül esküsznek a „nagy egész” kompozíciójának változás- vagy pillanatképére, éss továbbra

Engedtessék itt utalni egy történetileg pontosabb, időtávban méltányosabb, és Habermas alapvető hatását érdemben méltányoló kulcsfontosságú elemzésre: Felkai Gábor 1997 Két társadalomelméleti illúzió széttörése a jelenkori magyar közgondolkodáson. Forrás: http://www.c3.hu/ szf/Szofi97/Sz97-03/Sz97-03-Area-4.htm\#a32

2 Szerkesztette Kovách Imre, Szeged, 2017., 378 oldal 
is maradnak még, akik a mikrotörténések és apróbb folyamat-kanyarok réseiben, intimitásaiban megülő jelenségekre figyelnek több érdeklődéssel. Itt, ebben a könyvben is meghúzódik a rejtett szemléleti különbség, az értelem/racionalitás és a szervezet/bürokrácia közötti rejtekezések világáról. Az „átlátási” kísérletek persze egyre kevésbé tekinthetnek el (akár magasról-távolról nézzük, akár belülről-közelről) az életvilág „önálló létének” képtelenségeitől, s egyre erősebben érzékelik az életvilágok hatalmi szféra általi gyarmatosítási szándékait, a rákényszerítő hatásokat, a transzcendens képzetek melletti kökemény kényszereket is. Kereshetjük persze a Jürgen Habermas rendszerelméleti rálátásában rejlő sugallat szerint az életvilágban a szabadság, valamiféle testvériség, a jótétemények és a szolidaritás valamely megjelenését, sőt e remélt hatások értékének jeleit is a nyelvben vagy a személyek közti kölcsönhatásokban, de azt kell tapasztaljuk: a remélt életvilág-autonómia túlságosan elvontra és ideálisra sikeredett, a hétköznapi szerkezetmódosulás pedig jócskán időtálló lenyomatokat hagy a gazdaságos, tervezési, értékrendi, jövőtervezési és erkölcsi szférákban.

A kötethez az elöképek világából még hozzátartozik két köztes fogalmi képződmény, melyek mint ,alrendszerek” folytonosan keresik a maguk érvényesülési módjait, de folytonosan más és más rendszer-keretekhez illeszkednek: ezek egyike a feltételezett rendszerlogika eredményessége és abban a civilek, társadalmi öntevékenységek, helyi autonómiák esélye az önérvényesítésre, másrészt a regnáló hatalom eszköztára ahhoz, hogy a hatalom fogalmának definiálásával maga határozza meg, mi is az, amit definiálni kell - így persze befolyásol és legalizál politikai mintázatokat, jogi feltételeket, intézményi kereteket, illetékességi funkciókat, sőt végső soron a szocializációs kölcsönhatások kézbentartásával magát a politika fogalmát is, melyet amikor kiemel mint szakértelmezési szaktudásokat az össztársadalmi közbeszédből, ezzel mintegy rögtön a döntésjogot is elbitorolja a problematikus társadalomfejlődési jelenségek megnevezésének speciális illetékességével. Csöppet sem kéne itt azon igyekeznem, bizonyítani próbáljam a hatalom érzékenységét a rendszerjellemzők leírásában vállalt tudományos szerepet tekintve - s ezzel azt is kisajátítva, miképpen lehet struktúrafogalmakat forgalmazni anélkül, hogy magát a struktúrát érinteni és befolyásolni tudná. Amikor pedig a makroszociológiai kutatások egykönnyen vehetik azt az irányt, hogy KSH-adatokkal és saját mintavételi aprómunkával valami univerzálisan érvényes kontextust hozzanak össze magáról a társadalmi teljességről, akkor a struktúraformáló derivátumok egykönnyen veszik fel a politikai társadalom mikroközösségi különbségeiből fakadó érintettségi indulatkülönbséget, vagyis maguk is legitimálnak azzal, hogy legalizálják a látkép „objektív” voltát, s maximum ennek kicsiny fazonigazításával jelezhetik más tapasztalatukat...

A Kovách Imre szerkesztette kötet nem előzmények nélküli, hisz rokon szándékú-tartalmú korábbi össztársadalmi körkép is alig öt éve jött ki (munkatársaival közös) szerkesztésében a Társadalmi integráció a jelenkori Magyarországon, ${ }^{3} \mathrm{~s}$ a hívószó mindkét kötet esetében a társadalmi struktúra és az integráció - ami ha a létesítmény maga a Társadalom, akkor eszközei-elemei mi magunk vagyunk, kompozíciós egységben egymással állunk, valaki konstruált, összerakott, lebontott vagy újraformált bennünket. Persze jobbára kívülről, s nem mi magunk

Kovách Imre - Dupcsik Csaba - P. Tóth Tamás - Takács Judit szerk. 2012 Társadalmi integráció a jelenkori Magyarországon. Budapest, Argumentum Kiadó - MTA Társadalomtudományi Kutatóközpont (Szociológiai Intézet), 440 oldal 
vagyunk, aki megépítjük a társadalom „egészét”. Még azt a kicsiny helyet, teret, szerepet, amennyit betölthetünk egyáltalán, még azt is mások alkotják meg. S ki mások, s miért s mit alkotnak, meddig és kinek hasznára...?! Ezért aztán az, ahogyan egy emberekből álló világ felépül, összeáll, rétegekre osztható, önmagát is tagoló, s önnön részeinek egysége vagy egésze egyben több is lesz, mint számszerü teljesség, hisz mögötte-alatta ott lapul a társadalom összetartó erőhatása, kapcsolathálója, alrendszeri interakcióinak tömege is. Ez olykor hatalomként mutatkozik, máskor hatalmi eszközfunkcióban, megint máskor a létezés, az életvilág perspektívái, keretei, strukturális dimenziói adnak alakot neki. Szinte úgy, mint egy ház építésének akarása, kivitelezési terve és müködtetési modellje a tervezőasztalon, másik oldal felöl meg a szerkezet elemeinek, tartóoszlopainak, falainak, töltőanyagának rétegei, összetartó kompozíciói, erőhatásai is funkcionális alakot öltenek. Az egészben szerepet kapnak a részek - nevezzük integrációnak, amely összefog, s lássuk a térelemek viszonyát is - a „gépészeti” tartalmakat, a függelem vagy beékeltség mikéntjét, a rétegek tartós állapotát, tömörségét, időtállóságát. Talán erre van kitalálva a struktúrakutatás - ha nem éppen másra.

Ezért is van, hogy figyelmet ébreszt a leplezett és körülmagyarázott témakör révén a két könyv, melyek a társadalmi struktúráról szólnak, vagyis szerkezeti egészről, szervezeti teljességről, rétegeiről, összetételéről. A két kötet másik cím-komponense az integráció, vagyis a befogadó-felfogó, keretet adó és összetartó, a részek szerves összességének müködési főelvét képviselö fogalom. A szerkesztő Kovách Imre társadalomkutató, szociológus, egyetemi oktató, akadémiai doktor, intézményi vezető, elismert szaktekintély vagy negyedszázada, aki már a 2012-es kötetnél is meghatározó szerepet vitt. Söt, önmagában is izgalmas a két kötet hullámhosszainak párhuzamaira utalni, mert Kovách egész szakmai életútja valahol a rétegződés kérdései, az integráció mechanizmusai, a mechanizmusok és társadalmi tagoltsági alapkérdések körül formálódott, de újabb írásaiban jellegadó szerepet nyert a (talán korábban mechanikus strukturális modell névvel illethető, ma már egyre inkább) kulturális tőke, prekaritás, normák, értékrendek társadalmakat átható tónusa - mondhatnám valamely emberközelibb életkép-megjelenítés. S éppen e szempontból izgalmas a kollektív (2012-es) kötet tartalmának összehasonlító tükrözése a 2017-es integrációs/dezintegrációs témaválasztással. Az elöbbi - és fölöttébb hangsúlyozni kell: rendkívül impozáns szerzőgárdával - mintegy tizenöt-húsz oldalas tanulmányokból kiállított kötet önálló fejezetekbe tagolja üzenetét az értékek és bizalom, a települések és régiók, a gazdaság és munka, a befogadás és kizárás, valamint az egyének-csoportok-közösségek tematikai univerzumra építve. Vele kontrasztban a 2017-es tanulmány-válogatás integrációs mechanizmusok, rétegződés és integráció, normák és értékek, valamint kapcsolatok fejezetcímekkel kínál szerkezeti áttekintést. De kínálkozik a párhuzam (már a korábbi kötet bevezetőjében, Kovách Imre és Dupcsik Csaba szövegében) is arról: az utóbbi „ötven év társadalomtudományi irodalmában (és ennek hatására a közbeszédben) a társadalomszerkezet és az egyenlőtlenségek rendszere volt a domináns fogalmi keret, amelyben a magyar társadalomról szóló elemzések megszülettek. Ez a paradigmává vált tudományos beszédmód - annak ellenére, hogy ma is képes érvényes (rész)eredményeket termelni - az ezredfordulón 'elfáradt', és így kevésbé alkalmas a jelenkori, minden korábbinál összetettebb, gyorsabb társadalmi változások követésére” (2012:7.). Az új elméleti „keretfeltételek” leíró megalkotására elszánt kutatói kör, „szerényen” szólva a szakma egésze ebben az értelemben és minden más (módszertani, 
forrásfeltárási, kritikai, interpretációs, összehasonlítási, másodelemzési, empirikus, stb.) eltérések „feloldására” a társadalmi átmeneti fázisban éppen az integráció kulcsfogalmába vetíthető multidiszciplináris vagy interdiszciplináris megközelítések vállalását tekinthette megoldásnak - vagyis azt, hogy a ,posztmodern” társadalomkutatás újabb fogalmait, helyenként lokálisabb, máskor univerzálisabb spektrumát egy közbülső, még a vitás szerkezeti kérdések megoldása előtti problematika övezetébe terelhessék. Ekképpen a fogyasztás, az egyenlőtlenségek új rendszerei, a piaci szektorok viszonya, a szociábilis függésrendek új dimenziói is oly módon kerülhettek immár a későbbi kötet (és az azt megelőző hosszabb kutatási periódus, több intézményes partnerség kitermelte tudásanyag révén) megképződött tapasztalati anyagába, hogy azok újdonatúj rendszerré illeszthetők lehetnének talán.

A két kötet címe és ,alaptónusa” között is megnevezhető a különbség a 2017-es kötet esetében ,az újraelosztás és a hatalom szerkezete” fogalmak címbe emelésével. Persze, kutatóként amúgy is közvetlenül érdekelne, hogy az integráció bűvkörében mennyi az önkéntes, a belátásos, a kényszerü alkalmazkodás, és mennyi a közvetlenül vagy közvetetten „késztetett” és kényszerített behódol(tat)ás - vagyis ahogyan az integráció az asszimilációval találkozik a kisebbségi politizálásban -, de akkor még kiegészül az empirikus kutatói kérdés azzal is: mennyire esélyes, hogy integrációnak nevezzük a feltörekvés vágyát, a vele szembenálló alkalmazkodás politikáját, a beillesztés programját és a szándékolt kívülmaradás vágyát, s akkor „,vitatható”, eltérően értelmezhető annak lehetősége is, akar-e integrálódni valaki, s mibe, miért, hogyan, mikor, mennyi idő alatt, milyen következményekkel... De ez maradjon talán egy következő kötet kihívó problematikája! Amit itt nem tematizálnak, azt kár is számonkérni - csupán azért, mert esetleg más fogalmaim vannak, más szótáram alakult ki az integrálás témakörében! De az újabb kötethez visszatérve viszont azt látom, bár nem „,tematizálják, csak éppen követik..., s talán éppen ebben a lényegi összefüggésben látszik meghatározónak, ténylegesen ilyen perspektívából mutatkozik érvényesnek az áttekintő 2012-es kötet horizontjához képesti újjáformált kérdésfeltáró (s hátterében egy nagyobb szabású, sokszereplős, négyéves kutatási projekten alapuló) 2017-es könyv, mely önképe szerint ,új szempontból tekint a társadalmi egyenlötlenségekre. A kutatás eredményeként létrejött egy új egyenlötlenség modell, amely sokkal több szempontot figyelembe vesz a korábbi, munkajellegre alapozott rétegzödés modellekkel szemben, például a kapcsolatokat, a szubjektiv kirekesztettséget, a civil részvételt, a munkaintenzitást, az intézményi bizalmat vagy a normaszegés elfogadását. Az új modell alkalmas az egyenlötlenségek árnyaltabb kifejezésére, a dezintegráltság pontosabb mérésére, a középrétegek jellegzetességeinek a pontosabb leírására" (mint ezt a kötet ismertető szövege jelzi). Kovách Imre mint projektvezető és a kötet szerkesztője egyúttal az „Integrációs és dezintegrációs folyamatok a mai magyar társadalomban" kutatási tematika irányítója is, tehát egy fajsúlyos akadémiai program meghatározó irányváltását készíthette elő, amikor nevet, jelentőséget adott a vizsgálat egészén belüli az új utak keresésének, melyek főirányában a jelenkori magyar társadalom tagolódása és az egyenlőtlenségeket alakító folyamatok megismerési lehetősége kerülhetett közelebb szemléleti alapvetésként, közelebbről az integrációs mechanizmusok, modellek, újraelosztás és területiség problematikáihoz. Ehhez itt két momentumra is érdemes a figyelmet fókuszálni vagy hangsúlyt helyezni. 
Mindenekelőtt arra, hogy bár Kovách eredendő kutatási aspektusa a hajdani rétegződés-modellek megalkotási idejéhez (az 1980-as években Kolosi Tamás, Andorka Rudolf, Angelusz Róbert, Tardos Róbert és több más „struktúra-kutató” alaptevékenységéhez) képest markánsan gyarapodott a vidék- és településszociológia sokféle tematikájával, de erröl nem nekem kell „felfedezést” tennem, hanem már maga is megállapítja, hogy a kulcs-problémák körében a kortárs empirikus vizsgálatok tükrében (a modellek egzakt ismertetésén túl) a társadalom politikai integrációjának elemzése felé tértek el, ,ami eddig teljesen elhanyagolt terület volt”, s ezt gazdagítja immár „a jóléti és projektalapú redisztribúció” részletes, ,úttörőnek számitó” leírása, továbbá „, a társadalmi töke, a területiség és integráció összefüggéseinek leirása, a rétegzödés, a normák, a fogyasztás és integráció összefüggéseinek az elemzése, illetve a kapcsolatok integrativ szerepének az elemzése". A sokrétü és átfogó igényü ráközelítés ezúttal az értéknormák, kapcsolatok és lakóhelyiség dimenzióival is gazdagodik! Ez pedig fontos lépés, éppenséggel nem az integrációs problematikák ellenében, hanem irányában! Vagyis, fenti áttekintésem részbeni „visszaigazolásaként” a struktúrafogalmak és az életvilágbeli vagy kultúrafogalmak közeledésében itt egy komoly gazdagodás került előtérbe, amit nem kerülhetünk el a kontextuális értékeléskor.

Jóllehet, volna még több „felöl” és „felé” momentum is az egyfelöl-másfelöl értékelési szempontok mellett, de azt fölöttébb fontos hangsúlyozni, hogy érdemi figyelmet kap a kutatási-szerkesztési-megértetési szempontok között a rétegződés és változás, a társadalmi beilleszkedettség és viselkedésmodellek szerinti át- vagy újratagolódás szempontja is. A kérdésről a kötet kifelé tükrözött, piacképességet növelö sugallata szerint „a politikai viselkedést és értékorientációt nem lehet megérteni az egyének réteghelyzetéből, strukturális poziciójából kiindulva. Nem a társadalom szerkezete és állapota határozza meg a politikát, hanem sokkal inkább a politika integrálja a társadalmat"... - szól a kardinális meglátás. Ez pedig részint megerősíti az előző bekezdés tónusában már megjelenő aspektust, részint meg pontosítja, újabb színfoltot ad neki, aláhúzza jelentőségét. $S$ bár alább érzékenyítő aspektussal körvonalazom majd ezt, de itt rövid személyes vallomásra kell két mondatot szánjak...

Persze, nem két mondat, hanem két kiterjedt esettanulmány és számos, alaposan és részletesen hivatkozott szakirodalmi forrásutalás is kevés volna annak szabatos „,bevallásához”, hogy miképpen és mióta fogalmazok „magáncélra” kifejezetten a pártállami idők „engedélyezett”, „megtürt” rétegződéselméleti kutatásaival szembeni szakmai véleményt. Ezekből a nagyvolumenü, soktáblás, sokábrás, sokdecilises, sokmutatós-táblázatos-ábrás kutakodásokból nekem a nyolcvanas évek közepe óta durván és keményen hiányzik maga a létező Ember, a válaszadó egyén, a kapcsolathálói közt vergődő személyiség személyessége és hiteles kétkedése az egyedileg általa kiváltképpen befolyásolhatatlannak tünő társadalomkép megalkotása és megalkotói (a „,Szociomókusok”) ellenében. /Hiányzik persze a szociomókus emberképe, viselkedése, kérdéseinek oka, módja, érthetősége, illedelmessége, megölelő vagy leigázó mivolta is, de ez már technikai részletkérdésnek tekinthető inkább!/. Nem csupán kellő szakmai fölvértezettségem okán vagy hiányában vallom, de egyénként és kutatóként egyaránt azt vélem érvényesnek: lehessenek sokfélék a vélemények, a kifejezettek, a rejtettek, a leíróak, a személyesek, az intézményesek és így a kutatóiak is..., és lehessenek épp az emberközelség, a Személyiség vagy személyesség 
értékelésekor mélyebben érvényesek, amihez az is kell, hogy ne csupán a kutatásról, hanem magáról a kutatóról is többet tudjunk, még mielőtt akár a kérdését fölteszi, akár a válaszokat összegzi s közreadja. Ennek mint a kutatásetika evidens gyakorlatára vonatkozó kérdésnek csak roppant ritkán adtam hangot nyílt szakmai vita és virtuális ,győzelem” tónusában... - de érdemes hozzátenni, hogy példaképpen a kulturális antropológusok, olykor kommunikációkutatók vagy vizuális néprajzzal foglalkozók is megteszik, nem vagyok hát kivétel. De ezt az „objektív” társadalmi tudást „szubjektív” aspektusból értékelő nézőpontot azért kell itt megfogalmazzam, mert akár hozzáad, akár levon a referált kötet értékéből, azt nem a kötet, hanem a saját nézőpontom alapján érthetjük meg alaposabban. Kovách Imre több rendszerváltás utáni kötetéről nemcsak ismertetőket írtam, s nem csupán kutatóintézeti kollégájuk is voltam több évig, de épp az Általa kialakított fiatal kutató team egyre izgalmasabb és egyre mélyebb szakmai érdeklődésének kialakulásában közelről látom Kovách indokolhatóbb eredményességét, semmint további derivátumok és táblázatok tartományaiban. Úgy vélem tehát (az itt idézett, Kovách-bevallotta perspektíva-torzulás mellett, sőt ennek ellenében is), hogy ami a struktúra-specifikus leíró modellalkotásban éppen az utóbbi másfél-két évtizedben nóvumként jeleníthető meg, az valójában lehetett akár a fókuszváltás, a horizont-tágulás mögöttes oka is, de lehetett pusztán a szociológiatörténet hazai és nemzetközi sztenderdjeit követö összhatás is. Ugyanis ami egykor a társadalmi „struktúra-orientált” szervezeti adatok látószögében mindenkor prioritást kellett kapjon, talán szükségképpen egészült ki a nemcsak szervezet-specifikus, hanem éppen az érték-orientált, gyakorlat-orientált, (idővel persze a haszon-orientált, piac-orientált, gyakorlat-orientált, kommunikatív szférákat átható) másféle mikromodellek társadalmi tényeivel és normatív rendszereivel, $\mathrm{s}$ nem utolsósorban a Papp Zsolt, Bruszt László, Szakolczay Árpád, Hankiss Elemér közvetítette, korábban Habermas kidolgozta „,adaptációs stratégiák” másik kulcsfogalmával, a kultúra-orientált aspektussal. Úgy látom, s ezért úgy fogalmazom tehát, hogy a Max Weber-i értékmentesség követelményével a nyolcvanas években még „objektiválható” tudást legitimáló hazai struktúravizsgálatok sora (talán éppen a rendszerváltás során kibontakozni kezdő) kapitalizmus és a polgári demokratikus tervszabályozási átalakítás következtében mintha igényt formálna immár arra, hogy valamely virtuálisan megképződött új társadalmi struktúra és integrációs modell ellenoldalán végre elkezdje észrevenni a térbeli tagoltság szabta másságokat. E másságok között kiváltképp olyanokat, mint a polgári világ formális-ideológiai-értékrendi egyenlőségteremtő szabályozottságának hátterében meghúzódó esélyegyenlőtlenségi versenyhelyzetek, a gazdasági kihívásokból fakadó leszakadást és anómiát, munkamigrációt és újraelosztási érdekversenyt, a politikai integráció mögötteseként a politikai érdekcsoportok értékcsoportokká válását előidéző hatások. De hasonlóképpen a rétegződésben a szegmentációt és a végletes-tömeges-korosztályi-területi leszakadások gyarapodó tömegét, a normák és értékek integrációs problematikái között a közhasznúság és az esélykülönbségek elleni autonóm kezdeményezések létét és hálózatait, a kapcsolatkutatásokban a társadalmi szerepek, mentális örökségek, térségi függésrendek gazdag adatanyagát is, melyek mintegy a „társadalmi integráció” részeként képesek megfogalmazni a rászorultság, a közhasznúság, a leszakadás, a szolidaritás, avagy másképp megnevezve a korábbi struktúrát felülíró stratégiák meglétét, ezek sokasodását és adaptációs modellekké erösödését, vagyis a tágabb értelemben vett kultúra-orientált modellek egyre figyelemfelhívóbb rendszerének megnyilvánulásait (vagy ezek reprezentálódását és mérhetővé válását, beleértve a módszertani nóvumok kiteljesedési esélyeit is). 
Az a megoldás, hogy még mielőtt a kötetről részletekbe menően írnék, már jártam a messzi szociológiatörténeti pampákon, már beutaztam felívelő és leágazó modelleket, felkiáltójeleztem struktúrát és funkciós és kultúrát, a Kovách-életmühöz és tematikákhoz viszonyulásom változását, sőt az oeuvre bizonyos tónusainak változását (,innovációjának” érzékelését) is - nem elsősorban a magam elméleti kuszaságát vagy szakmai figyelmetlenségét tükrözik. Úgy vélem, egy mü értékéhez hozzátartozik az olvasóra bízott ismeretanyag „,kiolvasásának”, értésének, felhasználásának technikája is, az olvasó lázadása vagy partnerré avatása is, a szakmabeli elfogadó vagy elutasító gesztusai is, továbbá ezek oka és módja is. De, tegyem hozzá, úgy vélem, hogy épp ezzel a kutatói-olvasói-értelmezői pozícióval tehetem talán hitelessé, mit és miért tartok értékesnek a szóbanforgó kötetben. S mert az itt egyetlen lendülettel felsorolt új aspektusok már alapjaikban is tükrözik a két kötet közötti nemcsak időbeli, de kutatási horizontokban meglátszó kereszteződését, (vagy párhuzamossá válását akár), de sokban könnyítenek azon, hogy a tematikai korszakok közeledését mutatva önmagában is beszédes legyen a tartalomjegyzékből kivilágló „funkcióváltozási” vagy funkció-orientált kereső modell megannyi árulkodó eleme is. A 2017-es kötet Kovách Imre által írt fogalmi és megközelítési bevezetője, valamint a Kovách Imre - Hajdu Gábor - Gerő Márton - Kristóf Luca - Szabó Andrea értelmezésében megmutatott integrációs modell (7-48. old.) mintegy ráhangol az újraelosztás (Czibere Ibolya - Gerő Márton - Kovách Imre), a politikai integráció és az érdekcsoportok (Gerő Márton - Szabó Andrea), a társadalmi tőke integráló hatásainak kérdései (Hajdu Gábor - Megyesi Boldizsár), továbbá mindezek területiséggel összefüggő dimenziói (Csurgó Bernadett - Csizmady Adrienne - Kovách Imre) közötti „mechanizmusok” megnevezhetőségére (51-213. old.). Ezekre következően, s mivel a státuszcsoportok és az egyenlőtlenségek elméleti küzdelmében (a korábban kiegyezést nem lelő aspektusokat) mint ,paradigmaváltás igényét” megfogalmazó előmunkálatok kiteljesedő példatárát hivatkozza Kovách a fogalmi bevezetőben, pontosítva ezeket az „integráció és integrációs mechanizmus fogalmának értelmezéseit” bemutató rendszerező táblázatában (7-11. old.), okkal utal az alapozó kvalitatív modellkísérletek esélyeire is, hogy erre megerōsítésként a fogyasztással, normákkal, értékekkel és segítési hajlandósággal pontosítható fejezetben (217229. old.) vissza is térhessen, amire ezután Kovách Imre - Kristóf Luca - Szabó Andrea, meg Huszár Ákos - Sik Endre résztémái következnek megerősítésként a rétegződés-mérés további perspektíváival, hogy azután a fogyasztással, normákkal, értékekkel és segítési hajlandósággal pontosítható fejezetben Kristóf Luca - Szabó Andrea, valamint Koltai Júlia - Kristóf Luca Simonovits Bori a Bourdieu-féle töketípusok és a Kolosi-féle státuscsoportok ellenpontjaként az életstílus, életmodell, magaskultúra-fogyasztás, munkaerőpiaci integráltság empirikus anyagával igazolhassa egy újszerü kérdésfelvetés-komplexum kérdőíves megismerési lehetőségeit (267-304. old.). A záró blokk a kapcsolatoké, a hálózati tipológiáé, naplók és kötődések „egocentrikus" viszonyrendszerének kutatásáé, meg a lakóhelyé, ahol a társas kapcsolatok ugyancsak kitettek a régiók dezintegrációs, gyenge kötésekkel jellemezhető sodrásainak (így például a társ-hiányt érzékletesen leírhatóvá tévő dunántúli, közép- és keletmagyarországi szegénységi környezetek ,térképéé”), s ebben Albert Fruzsina - Dávid Beáta - Gerő Márton - Hajdu Gábor, továbbá Dávid Beáta - Lukács Ágnes - Huszti Éva - Barna Ildikó, illetve Koltai Júlia - Nemes Dóra szerzőcsapatok részletező tanulmányaié (307-375. old.). Utóbbiak révén mintegy térképzetként is láthatóvá válik, miként rejlik az integráció/dezintegráció függő mutatója is a községi, szegénységi, térségi beilleszkedettség eltérő modelljeiben, függő relációkban, innovációs 
kapcsolati potenciálokban vagy ezek hiányában, valamiféle bekebelezésben és kiszorításban egyaránt, „pluszok és mínuszok” egyenlegeinek kapcsolati naplóiban elkönyvelhetően. Annyi bizonyos viszont, hogy a teljes tartalomjegyzék, avagy az egyes írások „kijegyzetelt” és „értelemadó” kivonata kellőképpen reménytelen lenne itt - sőt épp a fenti „érdeklődési trendváltozás" okán a legkevésbé sem lenne érdemleges eljárás, ezért a továbbiakat és a részleteket még ennél is kevésbé volna illedelmes valamiféle „olvasati szentenciába” fordítani, mint a tanulságos áttekintések módszerbeli (és interpretációk alapján is eltérő) tételeit.

Ám épp a fenti felvezetés alapján immár bizonyosságot lelhetünk ama kihívásban, amit Kovách Imre és munkatársai (mondjuk egy klasszikusabb paradigma alapján) a habermasi „,rendszer” és „életvilág” ontológiai különbségei közötti összhang közvetett kutatásával, a strukturális kérdések funkcionális lenyomatainak állapotrajzával mégiscsak megneveztek. Ami ezekből is harsányan kikiált, az a demokratikus átmenet révén megerősödött modell-értékek málladozásának tapasztalata egyfelöl, a cselekvéselméleti ésszerüség és az instrumentális/kommunikatív racionalitás klasszikus perspektívái révén másik oldalról, melyek már talán széleskörüen ismerősek is mint deskriptív metódus részei. Látható (vagyis a Szerzők láttatják is), hogy az integrációs esélyek (elvileg magasabb, „makro-szintü”) modellizálhatósága csak részben múlik a politikai, pártszerü, társadalmi rétegszerkezetre emlékeztető mikro-univerzumokon, (az „alrendszer" mikrostrukturális elemein), mert mindezeket is egyre láthatóbban müködtetni képesek és hajlamosak a nem-formális érintkezési utak, magánéleti pályák, nyilvánossági relációk meghatározó komponensei. Ennyiben a társadalmi integráció magában rejt valamely szocializációs és kulturális értékrendet is, sőt, a résztanulmányok és egyes fejezetek ezek fontosságát is kiemelik. Közöttük például mintegy „klasszikusan” is valamely erkölcsi-politikai célok (demokratikus feltételek melletti) képzetét, ilyesmik kialkudásának igényét vagy esélyét is lehetségessé tevő hatásokat, e hatások kölcsönhatásokká alakulását, a visszahatások rejtelmeit és tónusait ugyancsak. Ugyanakkor - mert a társadalom bázisait, materiális újratermelését elvégző makro-rendszer szervesen is kapcsolódhat/kapcsolódik az életvilág belső racionalitásához -, ez mintegy elöjön, megjelenik akár a térségi, akár a civil szerveződési, autonóm, nem-intézményes rendszer-követelmények jogi és morálisan-mentálisan lehetséges szféráiban is, melyekről a tanulmányok több metszetben szólnak is. Itt a rétegződési komponensekhez tapadó technikai-technológiai modernizációk bár látványos területi különbségekkel tündökölnek, valahol messze távol mégis megokolt elvárásként, innovatív esélyként, a közösségi életvilágok szintjein pedig már az emberi csoportok horizontján is lehetséges perspektívákként megjelenhetnek. Ennek hol része, hol szerves tartozéka, hol következménye vagy késői járuléka a közösségi anómiák jelenléte, az életvilág gyarmatosítása, a kiszolgáltatottság minőségének árnyaltabb, de intenzívebb müködtetése - amire persze az integráló rendszer tartós müködésének feltételezésével, a hatalmi szerep struktúrába épülő és egyre merevedő, vagy olykor hektikusan változó következményeire már szinte számítani is lehet. Vagyis: a változás a struktúrában még nem változtat a kultúrában, ahogy Habermas mondaná! Sőt, a társas vagy társadalmi kiszolgáltatottság sem okvetlenül módosít az integrációs modelleken, hanem rejtett lehetőségként ott marad magában a rendszerben a közösségi szintủ szabadságfeltételek lehetséges igénye is. Továbbá megbúvik még a rendszer intézményei (nemzetgazdaság, párt-államhatalom, totalizált közigazgatás, civil jogérzékenység, mozgalom-szintủ társas elégedetlenség) szféráiban valahol ott is, 
ahol a hiábavaló stratégiai és bürokratikus sikerképesség morális deficitje, az igazságosság mindenkori érzületének rejtekező minimuma, valamint a kialakult érdekkonfliktusok tompítására alkalmas ellenoldali mechanizmusok számos célrendszere, értékképzete lakozik. Ezek ugyan a struktúraformáló folyamatok terén talán kevéssé számszerüsíthetők, nem is mindig „,egynemüen" megnevezhetők, ám a szolidaritás, az egyeztethető érdekek vagy a megjeleníthető értékek terén mégis társas interakciókban kereshetnek önmegjelenítési utat $-\mathrm{s}$ keresnek, sőt találnak is. Márpedig ez az út, vagy ilyen utak, ezáltal pedig az integráció további esélyeinek efféle mechanizmusai azok, amelyeknek változó alaptónusa, a széttagolódás és dezintegrálódás kíméletlenné válása volt a 2012-es kötetnek is alaphangja, így hát annyira nagy tévedésben mégsem voltam a két mü közelségét, egymásra vetíthetőségét illetően, ha a 2017-es könyvben ugyancsak jelen van. De kétségtelen, hogy az öt esztendővel későbbi tanulmány-válogatás az integrációs folyamatok kevesebb, viszont mélyebb zavaraira, ezzel pedig a kulturális folyamatok zavaró leépülésére, immár kínos válságtüneti jellé válására mutatnak az újabb tanulmányok.

Mindazonáltal lehet persze, hogy a morális, transzcendentális vagy kevésbé struktúraalkotó kölcsönhatások nem mérhetők ugyanúgy, mint a rétegképző vagy integráltsági mutatókkal ékesíthető társadalmi tények. Ám ezek jelenlétét talán már az efféle újabb integrációs kutatások is méltóképpen tükrözhetik (lehessen talán itt utalni a kötetben az érdekek integrációs mutatóira Gerő Márton aspektusai között, a szegmentáció és prekariátus jellegadó jegyeire Sik Endre megfigyeléseiben, az újraelosztás tudástőke vagy értékmodellek vonzásköre szempontjából fontos momentumaiban Czibere Ibolya adatai szerint, a fogyasztás értékrendi normáinak esetében Kristóf Luca és Simonovics Bori témakörében, vagy a „kapcsolati naplózás” jelzéstára szempontjából fontos komponensek esetében Albert Fruzsina, Dávid Beáta, Barna Ildikó és munkatársaik munkáiban).

Ráadásul valamiképp a 2017-es kötet egésze is érzékenyebben bánik a ráhangoltság, a közhasznúság, a kiszolgáltatottság, az elfogadottság vagy beilleszkedettség apró rezzenéseinek megfogalmazhatóságával. S ez jó iránynak mondható, ez előzmények tükrében fölöttébb. Ezzel együtt is érdemes még zárásképpen utalni az emberi viszonyok jellemző racionalitásai, az életvilág komponensei közötti érték-orientációk eltérései, és a rendszerszintü strukturális függésrendek egyenlőtlenségi modelleket kínáló magyarázatai közötti értelmezési különbségekre, a mediatizált függésrendek és újraelosztásra kerülő tőketulajdonok (pénz, tudás, térbeli tagoltság, mobilitások, hozott készségek, befogadási érzékenységek, stb.) változásai közepette megmutatkozó tünetekre. Ezek ugyanis legtöbbször (vagy jó eséllyel) a hatalom kizáró, elkülönítő médiumától elszenvedett kiszolgáltatottság (kizárás, háttérbe szorítottság, leradírozódás, elesettség) bürokratikus mechanizmusait is visszaható módon erősítik, tehát sokszor még a jószándékú megoldási-segítségi-kompenzálási kísérletek is úgy hatnak vissza, hogy abból nem a biztató változás, hanem a mélyebbé váló válságjelek, a begyürődések és elmaszatolódások, esélytelenség-növekmények egyre kiterjedtebb összhatása következik. De pont ezért, s egyre inkább érdemes figyelembe venni a társadalmi eligazodás, célok, értékrendek akut változásai sorában, az integrációs jel-együttes, tünetek és következményeik terén mindazt, ami részben erősödő válságjel, részben gyengülő reakcióképesség, részben lemondó türéshelyzet, jövőnélküli világkép alapélménye. Így tehát, ha korunk újabban épp a hatalmi ügyvivőkörből mind harsányabban 
szorgalmazott és elvárt „hasznossági” és érvényességi mutatóit vesszük, éppen ehhez, és a szakmai kutatási horizonton az új modellek lehetőségeihez, a társadalom integráltsági állapotának leképezési irányaihoz járul hozzá Kovách Imre és munkatársainak újabb kötete. Nem elöször, s reméljük, nem is utolsó kísérletként. A struktúra-orientált társadalomkép fokozódó kiegészülése a kultúra-orientált életképekkel nem csupán kutatási stratégiai problematika vagy folyamat, hanem a még valamely szinten mégiscsak létező társadalmi helyzetérzékenység egyik állapotjelzője is. Ha „csak” integrációs, ha csak hatalmi, de végső soron feltünően esélyegyenlőtlenségi, partnerhiányossági, kapcsolathálózati deficit értelmében mindenképpen. 